Louisiana State University

LSU Digital Commons

Faculty Publications

Department of Biological Sciences

8-1-2011

\title{
Inhibition of neutrophil apoptosis by PAI-1
}

Jaroslaw W. Zmijewski

The University of Alabama at Birmingham

Hong Beom Bae

The University of Alabama at Birmingham

Jessy S. Deshane

The University of Alabama at Birmingham

Cynthia B. Peterson

The University of Tennessee, Knoxville

David D. Chaplin

The University of Alabama at Birmingham

See next page for additional authors

Follow this and additional works at: https://digitalcommons.Isu.edu/biosci_pubs

\section{Recommended Citation}

Zmijewski, J., Bae, H., Deshane, J., Peterson, C., Chaplin, D., \& Abraham, E. (2011). Inhibition of neutrophil apoptosis by PAI-1. American Journal of Physiology - Lung Cellular and Molecular Physiology, 301 (2) https://doi.org/10.1152/ajplung.00075.2011

This Article is brought to you for free and open access by the Department of Biological Sciences at LSU Digital Commons. It has been accepted for inclusion in Faculty Publications by an authorized administrator of LSU Digital Commons. For more information, please contact ir@lsu.edu. 


\section{Authors}

Jaroslaw W. Zmijewski, Hong Beom Bae, Jessy S. Deshane, Cynthia B. Peterson, David D. Chaplin, and Edward Abraham 


\title{
Inhibition of neutrophil apoptosis by PAI-1
}

\author{
Jaroslaw W. Zmijewski, ${ }^{1}$ Hong-Beom Bae, ${ }^{1,2}$ Jessy S. Deshane, ${ }^{3}$ Cynthia B. Peterson, ${ }^{4}$ David D. Chaplin, ${ }^{3}$ \\ and Edward Abraham ${ }^{1}$ \\ Departments of ${ }^{1}$ Medicine and ${ }^{3}$ Microbiology, University of Alabama at Birmingham, Birmingham, Alabama; ${ }^{2}$ Department \\ of Anesthesiology and Pain Medicine, Chonnam National University Medical School, Republic of Korea; and ${ }^{4}$ Department \\ of Biochemistry and Cellular and Molecular Biology, University of Tennessee at Knoxville, Knoxville, Tennessee
}

Submitted 8 March 2011; accepted in final form 24 May 2011

\begin{abstract}
Zmijewski JW, Bae H, Deshane JS, Peterson CB, Chaplin DD, Abraham E. Inhibition of neutrophil apoptosis by PAI-1. Am J Physiol Lung Cell Mol Physiol 301: L247-L254, 2011. First published May 27, 2011; doi:10.1152/ajplung.00075.2011.-Increased circulating and tissue levels of plasminogen activator inhibitor 1 (PAI-1) are often present in severe inflammatory states associated with neutrophil activation and accumulation and correlate with poor clinical outcome from many of these conditions. The mechanisms by which PAI-1 contributes to inflammation have not been fully delineated. In the present experiments, we found that addition of PAI-1 to neutrophil cultures diminished the rate of spontaneous and TNFrelated apoptosis-inducing ligand-induced apoptotic cell death. The effects of PAI-1 on cell viability were associated with activation of antiapoptotic signaling pathways, including upregulation of $\mathrm{PKB} / \mathrm{Akt}$, $\mathrm{Mcl}-1$, and $\mathrm{Bcl}-\mathrm{x}_{\mathrm{L}}$. Although urokinase-plasminogen activator receptor, lipoprotein receptor-related protein, and vitronectin are primary ligands for PAI-1, these molecules were not involved in mediating its antiapoptotic properties. In contrast, blocking pertussis toxin-sensitive $\mathrm{G}$ protein-coupled receptors and selective inhibition of phosphatidylinositide 3-kinase reversed the ability of PAI-1 to extend neutrophil viability. The antiapoptotic effects of PAI-1 were also evident under in vivo conditions during LPS-induced acute lung injury, where enhanced apoptosis was present among neutrophils accumulating in the lungs of PAI- $1^{-/-}$compared with PAI- $1^{+/+}$mice. These results demonstrate a novel antiapoptotic role for PAI-1 that may contribute to its participation in neutrophil-associated inflammatory responses.
\end{abstract}

inflammation; acute lung injury

ALTHOUGH NEUTROPHILS PLAY a beneficial role in the eradication of invading microorganisms, exaggerated proinflammatory activities of these cells can contribute to prolonged inflammation, tissue damage, and organ injury in inflammatory processes such as acute lung injury (ALI) or sepsis (1, 10). In such neutrophil-driven inflammatory conditions, apoptotic cell death and subsequent clearance to prevent the release of harmful proinflammatory mediators from dying cells are essential mechanisms for resolution of inflammation $(19,32)$. The prolonged presence of activated neutrophils in the lungs and other organs involved in inflammatory processes, including during ALI and myocardial ischemia, contributes to greater severity of organ injury in these settings $(17,20)$.

Apoptosis in neutrophils occurs through pathways similar to those observed in other cell populations and involves caspase activation, cell membrane blebbing, loss of mitochondrial membrane potential $\left(\Delta \psi_{\mathrm{m}}\right)$, and externalization of phosphatidylserine (16). Previous studies have found that the lifespan of neutrophils is prolonged after exposure to LPS or proinflam-

Address for reprint requests and other correspondence: E. Abraham, Dept. of Medicine, Univ. of Alabama at Birmingham School of Medicine. BDB 420, 1530 3rd Ave. S, Birmingham, AL 35294-0012 (e-mail: eabraham@uab.edu). matory cytokines, such as IL-1 $\beta$, whereas cyclin-dependent kinase inhibitors or suppression of prosurvival signaling pathways, particularly those involving Akt or cAMP/PKA, increases neutrophil apoptosis $(30,42)$.

PAI-1 is a multifunctional protein that belongs to the SERPIN superfamily of serine protease inhibitors (25). Plasminogen activator inhibitor 1 (PAI-1) is an effective inhibitor of plasminogen activators, particularly urokinase-plasminogen activator (uPA) and tissue-type plasminogen activator, and binds to the LDL receptor (LRP) and vitronectin $(25,33)$. Although increased levels of PAI-1 and inhibition of plasmin generation are found in the lungs and circulation of critically ill patients with sepsis or ALI $(28,40)$, recent studies have also shown that PAI-1 can affect a broad range of cellular functions independent of its effects on coagulation, including cell adhesion, proliferation, migration, and viability $(6,21,36)$. In particular, PAI-1 can facilitate neutrophil chemotaxis, enhance release of cytokines by Toll-like receptor 4-stimulated neutrophils, and diminish the uptake of apoptotic neutrophils by macrophages $(23,26)$.

Several studies have demonstrated that PAI-1 participates in regulating cell viability, with pro- and antiapoptotic effects being reported $(6,11)$. However, there is no information concerning a potential role for PAI-1 in modulating neutrophil viability and apoptosis. In the present experiments, we found a novel function for PAI-1 in diminishing apoptosis of neutrophils under in vitro and in vivo conditions.

\section{MATERIALS AND METHODS}

Mice. PAI-1 knockout mice backcrossed with C57BL/6 mice for at least nine generations and age- and sex-matched control C57BL/6 mice were obtained from Jackson Laboratory (Bar Harbor, ME). All experiments were conducted in accordance with protocols approved by the University of Alabama at Birmingham Institutional Animal Care and Use Committee.

Reagents and antibodies. Antibodies to phosphorylated and total Akt, Erk1/2, cAMP response element-binding protein (CREB), Bcl$\mathrm{X}_{\mathrm{L}}$, and Mcl-1 were purchased from Cell Signaling (Beverly, MA); antibody to actin and polymyxin B from Sigma Chemical (St. Louis, $\mathrm{MO}$ ); and propidium iodide and antibodies to annexin $\mathrm{V}$ from EMD Chemicals (Gibbstown, NJ). Recombinant mouse PAI-1 and mutant PAI-1 (R76E) or PAI-1 (R101A/Q123K) proteins were gifts from Dr. Victoria Ploplis (Notre Dame, IN). Mouse vitronectin was purchased from Abcam (Cambridge, MA); recombinant TRAIL/TNFSF10 from R \& D Systems (Minneapolis, MN); Hoechst 33342 from Invitrogen (Carlsbad, CA); and CD11b-phycoerythrin (PE) antibody from BD Pharmingen (San Diego, CA).

Neutrophil isolation and culture. Bone marrow neutrophils were isolated as previously described (50). Neutrophil purity was consistently $>97 \%$, as determined by Wright-Giemsa-stained cytospin preparations. Neutrophils were cultured in RPMI 1640 medium containing $5 \%$ FBS and treated as indicated. 
Measurement of neutrophil apoptosis. The percentage of early and late apoptotic cells was determined by staining the cells with annexin V-FITC and propidium iodide and studying the cells by flow cytometry (13). Caspase-3 and -9 activities were measured using standard fluorogenic substrates (Calbiochem, La Jolla, CA), in conjunction with epifluorescent microscopy. Briefly, neutrophils $\left(1.5 \times 10^{6} /\right.$ well $)$ were treated as indicated, transferred to $1.5-\mathrm{ml}$ centrifuge tubes, and washed twice with serum-free RPMI 1640 medium. The neutrophils were incubated with cell-permeable caspase- 3 or -9 fluorogenic substrate for $60 \mathrm{~min}$ at $37^{\circ} \mathrm{C}$, and Hoechst $33342(1 \mu \mathrm{g} / \mathrm{ml})$ was added for an additional $15 \mathrm{~min}$ to stain the nuclei. The cells were washed with RPMI 1640 medium and transferred to a four-well chambered coverslip (Nalge, Naperville, IL), and images were acquired using a Leica DM IRBE inverted epifluorescence/Nomarski microscope outfitted with laser confocal optics (TCS NT, Leica, Exton, PA). The level of the fluorescence product (for caspase-3 or -9) and number of nuclei $\left(2-3 \times 10^{5}\right.$ cells/field) were measured in randomly acquired fields using SimplePCI software (Compix, Cranberry Township, PA). Data were calculated as the ratio of green fluorescence to number of nuclei. Final images were processed and stored using IPLab Spectrum and Adobe Photoshop software (Adobe Systems, San Jose, CA). $\Delta \psi_{\mathrm{m}}$ was determined using the cell-permeable probe JC-1 and confocal microscopy, as previously described $(34,49)$.

Western blot analysis. Cells were prepared in lysis buffer $[50 \mathrm{mM}$ Tris, pH 7.4, $150 \mathrm{mM} \mathrm{NaCl}, 0.5 \%$ (vol/vol) NP-40, 1 mM EDTA, 1 mM EGTA, $1 \mathrm{mM} \mathrm{Na}_{3} \mathrm{VO}_{4}, 50 \mathrm{mM} \mathrm{NaF}$, and protease inhibitors] and then sonicated and centrifuged at $10,000 \mathrm{~g}$ for $15 \mathrm{~min}$ at $4^{\circ} \mathrm{C}$. The protein concentration in supernatants was determined using Bradford reagent (Bio-Rad, Hercules, CA) with BSA as a standard $(46,48)$. Samples were mixed with Laemmli sample buffer and boiled for 5 min. Equal amounts of protein were resolved by $8 \%$ SDS-PAGE and transferred onto polyvinylidene difluoride membranes (Immobilon $\mathrm{P}$, Millipore, Billerica, MA). The membranes were probed with specific antibodies to detect total and phosphorylated Akt, Erk1/2, and CREB, as well as $\mathrm{Mcl}-1$ or $\mathrm{Bcl}-\mathrm{x}_{\mathrm{L}}$. Bands were visualized by enhanced chemiluminescence (SuperSignal, Pierce Biotechnology, Rockford, IL). Each experiment was carried out two or more times using neutrophils obtained from separate groups of mice.

ALI model. ALI was induced by intratracheal administration of 1 $\mathrm{mg} / \mathrm{kg}$ LPS in $50 \mu \mathrm{l}$ of PBS, as previously described $(15,44,47,48)$. Briefly, mice were anesthetized with isoflurane and then suspended by their upper incisors on a $60^{\circ}$ incline board. The tongue was gently extended, and LPS solution was deposited into the pharynx $(9,48)$. Lungs were harvested $24 \mathrm{~h}$ after LPS administration.

Measurement of neutrophil apoptosis in vivo. Infiltrating leukocytes were isolated from minced lung tissue by treatment with collagenase B (2 mg/ml; Roche) and DNase I (0.02 mg/ml; Sigma Chemical) in Iscove's modified Dulbecco's medium supplemented with $1 \mathrm{mM}$ sodium pyruvate, $2 \mathrm{mM}$ L-glutamine, $10 \mu \mathrm{g} / \mathrm{ml}$ penicillinstreptomycin, $25 \mu \mathrm{M}$ 2-mercaptoethanol, and $0.1 \mathrm{mM}$ nonessential amino acids (Life Technologies) at $37^{\circ} \mathrm{C}$ for $30 \mathrm{~min}$. Then an equal volume of Iscove's modified Dulbecco's medium containing 20\% FBS was added. Cell suspensions were passed through a $40-\mu \mathrm{m}$ cell strainer and washed with PBS. To determine the percentage of apoptotic neutrophils, the cells were incubated with annexin V-FITC and CD11b-PE antibodies and then analyzed by flow cytometry. In selected experiments, cells isolated from lung digests were incubated with caspase-9 fluorogenic substrate for $60 \mathrm{~min}$ and with CD11b-PE antibody for an additional $30 \mathrm{~min}$ at $37^{\circ} \mathrm{C}$ and then subjected to flow cytometry.

Statistical analyses. Student's $t$-test was used for comparisons between two groups. Tukey's test was used for comparisons between more than two groups. $P<0.05$ was considered to be statistically significant.

\section{RESULTS}

Exposure to PAI-1 diminishes spontaneous apoptosis in neutrophils. In initial experiments, the percentage of viable and apoptotic cells was determined among neutrophils cultured with or without recombinant PAI-1 for 24, 48, or $72 \mathrm{~h}$. Although neutrophil apoptosis increased upon culture of cells for $24 \mathrm{~h}$, the difference between control and PAI-1-treated cells was not significant. However, as shown in Fig. 1, neutrophils cocultured with PAI-1 for 48 or $72 \mathrm{~h}$ demonstrated significantly decreased apoptosis compared with cells cultured in the absence of PAI-1. One application of PAI-1 was sufficient to increase neutrophil viability (Fig. $2 B$ ). The activity of caspase-3 and -9 was decreased in neutrophils exposed to PAI-1 (Fig. 3, $A$ and $C$ ). Exposure to PAI-1 preserved $\Delta \psi_{\mathrm{m}}$, which normally declines in untreated cells during apoptosis (Fig. 3, $B$ and $C$ ). To confirm that the antiapoptotic effects of PAI-1 were not due to contamination with LPS, we added polymyxin B to the cultures and found that whereas polymyxin B prevented LPSmediated increases in neutrophil viability, addition of polymyxin B to cultures containing PAI-1 did not affect the antiapoptotic actions of PAI-1 (Fig. 2A). The concentrations of PAI-1, i.e., $100-1,000 \mathrm{ng} / \mathrm{ml}$, that resulted in diminished apoptosis of neutrophils are physiologically relevant, with similar PAI-1 levels having been reported in the lungs and in the circulation of critically ill patients with sepsis or ALI $(28,40)$.

To determine the temporal relationship between exposure to PAI-1 and inhibition of apoptosis, neutrophils were cultured with PAI-1 for $0,4,8$, or $24 \mathrm{~h}$, washed, and cultured without PAI-1 for a total of $48 \mathrm{~h}$. In parallel experiments, neutrophils were cultured without PAI-1 for 4,8 or $24 \mathrm{~h}$, and PAI-1 was added to the medium before the cells were collected after a total culture period of $48 \mathrm{~h}$. As shown in Fig. 4, $A$ and $B$, addition of PAI-1 to the neutrophil cultures after $8 \mathrm{~h}$ or withdrawal of PAI- 1 after $4 \mathrm{~h}$ of culture resulted in lack of any effect on neutrophil apoptosis. These results indicate that exposure of neutrophils to PAI-1 $4-8 \mathrm{~h}$ after initiation of culture was essential for its antiapoptotic effects.

Exposure of neutrophils to PAI-1 induced activation of antiapoptotic signaling pathways. In particular, as shown in Fig. $4 C$, culture of neutrophils with PAI-1 for 4,8 , or $16 \mathrm{~h}$ resulted in enhanced activation of Akt, phosphorylation of CREB, and increased intracellular levels of the antiapoptotic proteins $\mathrm{Mcl}-1$ and $\mathrm{Bcl}-\mathrm{X}_{\mathrm{L}}$. These results are consistent with previous studies in which Mcl-1 was shown to be a major antiapoptotic factor in neutrophils $(2,39)$.

PAI-1-dependent activation of phosphatidylinositol 3-kinase is essential for diminished apoptosis in neutrophils. Although enhanced phosphorylation of Akt and CREB and increased levels of Mcl-1 were found in PAI-1-treated neutrophils, it is not clear whether activation of phosphatidylinositol 3-kinase (PI3-K) or PKA signaling pathways was a predominant mechanism involved in the antiapoptotic effects of PAI-1. To examine this issue, neutrophils were cultured with or without the PKA inhibitor H-89 or the PI3-K inhibitor wortmannin. As shown in Fig. 5A, whereas inhibition of PKA or PI3-K resulted in enhanced neutrophil apoptosis, coculture with PAI-1 increased the viability of neutrophils treated with $\mathrm{H}-89$, but not with wortmannin. These results suggest that activation of $\mathrm{PI} 3-\mathrm{K}$, but not PKA, is required for the inhibition of neutrophil apoptosis by PAI-1. In addition, treatment of neutrophils with 
A
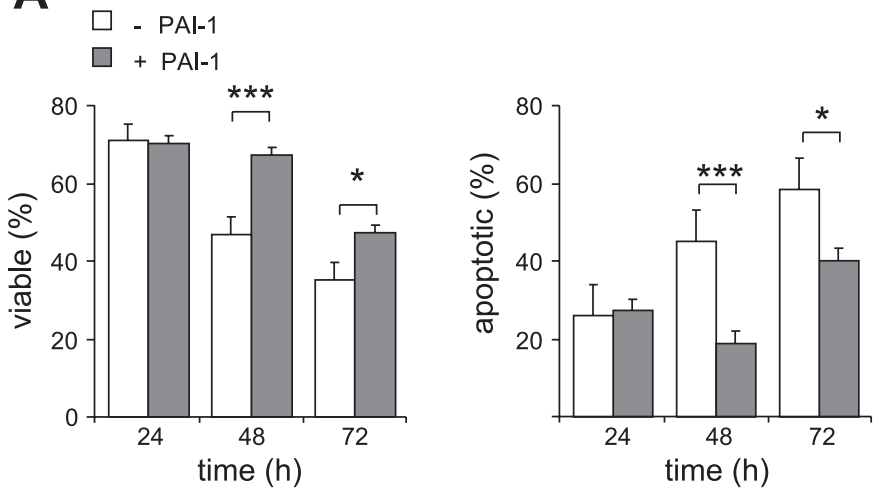

B

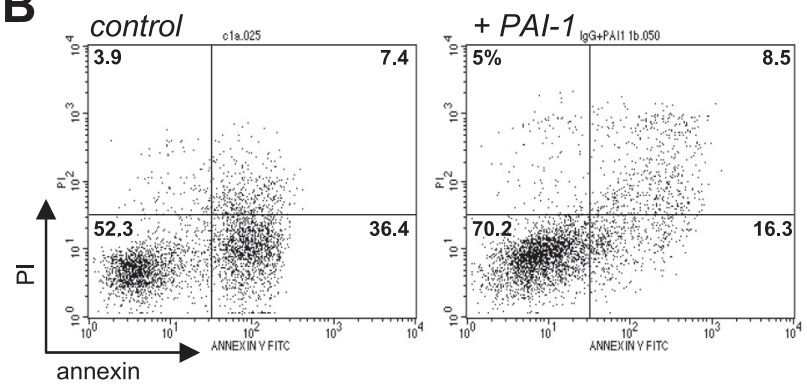

C

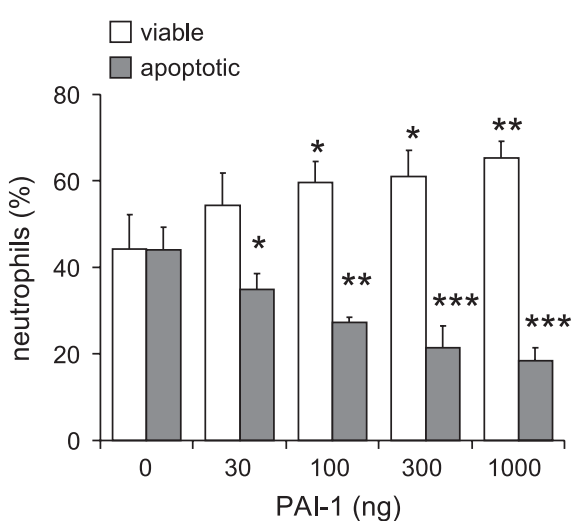

Fig. 1. Effects of plasminogen activator inhibitor 1 (PAI-1) on spontaneous apoptosis among neutrophils. A: viability and progression to apoptosis in neutrophils incubated with PAI-1 ( 0 or $500 \mathrm{ng} / \mathrm{ml}$ ) for 24,48 , or $72 \mathrm{~h}$. Values are means $\pm \mathrm{SD}(n=3) . * P<0.05, * * * P<0.001$ vs. untreated cells. $B$ : representative flow cytometry results showing percentages of viable [i.e., annexin V-negative/propidium iodide (PI)-negative (bottom left)], early apoptotic [i.e., annexin V-positive/PI-negative (bottom right)], late apoptotic [i.e., annexin V-positive/PI-positive (top right)], and necrotic [i.e., annexin Vnegative/PI-positive (top left)] neutrophils after culture with PAI-1 (0 or 500 $\mathrm{ng} / \mathrm{ml})$ for $48 \mathrm{~h}$. $C$ : neutrophils were cultured with PAI-1 (0, 30, 100, 300, or $1,000 \mathrm{ng} / \mathrm{ml}$ ) for $48 \mathrm{~h}$, and percentages of apoptotic and viable neutrophils were determined by flow cytometry. Values are means $\pm \operatorname{SD}(n=3)$. $* P<0.05, * * * P<0.001$ vs. untreated cells.

PAI-1 and H-89 diminished phosphorylation of CREB and the levels of Mcl-1 but had no effect on activation of Akt (Fig. 5B). In contrast, exposure of neutrophils to wortmannin and PAI-1 blocked phosphorylation of Akt but did not completely prevent the increases in Mcl-1 or phosphorylated CREB in PAI-1treated neutrophils. These experiments demonstrate that activation of PI3-K is a major contributor to the antiapoptotic effects of PAI-1.
Antiapoptotic effects of PAI- 1 are dependent on $G$ proteincoupled receptor but are independent of $U P A R, L R P$, and vitronectin. Previous studies showed that PAI-1 can bind to the uPA (uPAR) and LDL (LRP) receptors and also forms complexes with vitronectin, resulting in modulation of signaling pathways involving $\alpha_{V} \beta_{3^{-}}$and other integrins $(22,35)$. Given the ability of uPAR, LRP, and vitronectin to influence cellular viability in many cell populations $(4,8)$, we examined their role in mediating the delay in neutrophil apoptosis induced by PAI-1.

In initial experiments, recombinant [wild-type (WT)] PAI-1 or the PAI-1 mutants R76E and PAI-R101A/Q123K, which do not bind to LRP or vitronectin, respectively, were used (37, 43). Apoptosis was inhibited to a similar degree by culture of neutrophils with R76E or R101A/Q123K and with WT PAI-1 (Fig. 6A). Exposure to PAI-1 decreased apoptosis to approximately the same extent in neutrophils from vitronectin-deficient $\left(v \mathrm{tn}^{-/-}\right)$mice and neutrophils from control $v \mathrm{tn}^{+/+}$mice (Fig. $6 B$ ). Preincubation of PAI-1 with vitronectin resulted in loss of the ability of PAI-1 to inhibit neutrophil apoptosis (Fig. 6B). These results suggest that whereas preexposure to

A
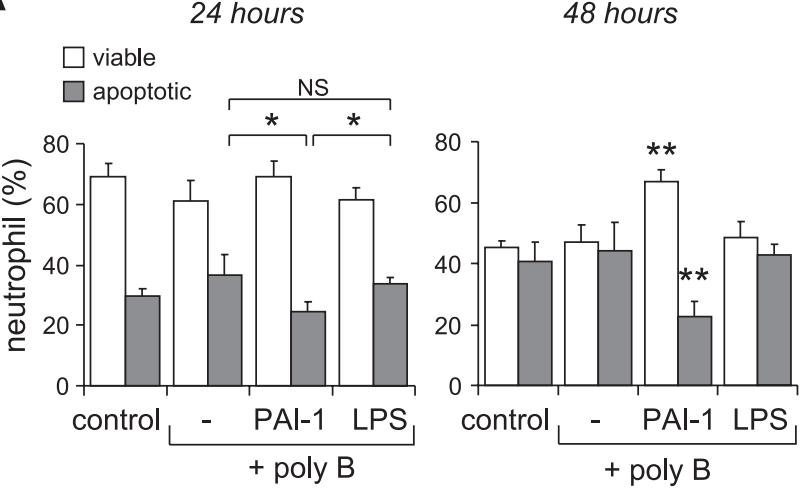

B
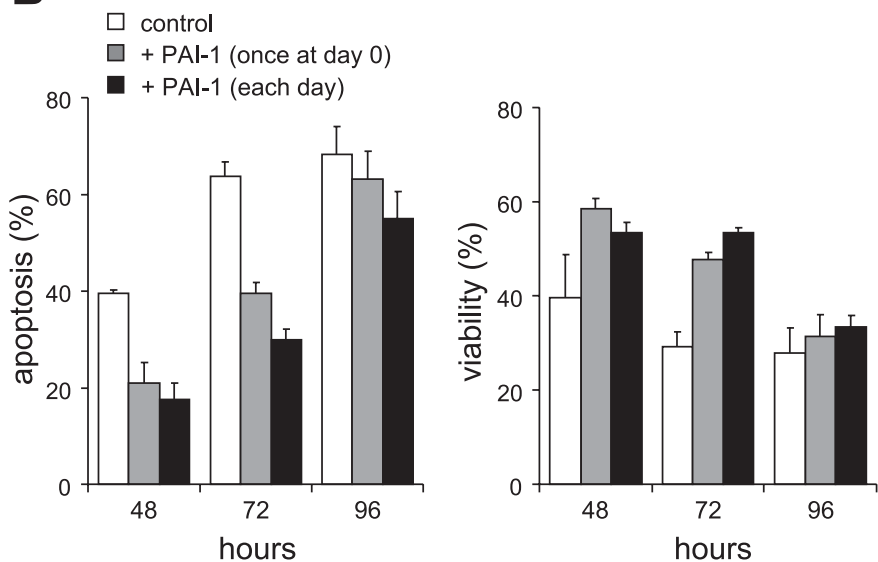

Fig. 2. Effects of PAI-1 on neutrophil apoptosis. A: percentages of viable and apoptotic neutrophils after incubation with PAI-1 $(0$ or $500 \mathrm{ng} / \mathrm{ml})$ or LPS $(0$ or $100 \mathrm{ng} / \mathrm{ml}$ ) for 24 or $48 \mathrm{~h}$. Polymyxin B (poly B; 0 or $10 \mu \mathrm{M}$ ) was added to neutrophil cultures $30 \mathrm{~min}$ prior to inclusion of PAI-1 or LPS in the cultures. Values are means $\pm \mathrm{SD}(n=3)$. NS, not significant. $* P<0.05, * * P<0.01$ vs. untreated or culture with polymyxin $\mathrm{B}$ alone. $B$ : viable and apoptotic neutrophils after addition of PAI-1 $(500 \mathrm{ng} / \mathrm{ml})$ only at initiation of the cultures or after addition of PAI-1 $(500 \mathrm{ng} / \mathrm{ml})$ to the cultures every $24 \mathrm{~h}$ starting with initiation of culture. Values are means \pm SD of results from 2 independent experiments. 
Fig. 3. Effects of PAI-1 on caspase- 9 and -3 activation and mitochondrial membrane potential $\left(\Delta \Psi_{\mathrm{m}}\right)$ in neutrophils undergoing spontaneous apoptosis. A: neutrophils in 4-well chambered coverslips were cultured with PAI- 1 ( 0 or $500 \mathrm{ng} / \mathrm{ml}$ ) for $48 \mathrm{~h}$; then cells were loaded with fluorogenic substrates for caspase- 3 or -9 and Hoechst 33342 to assess caspase activity and total number of cells per image, respectively. Representative images show fluorescence level in control and PAI-1-treated cells. $B$ : neutrophils were cultured with PAI-1 (0 or $500 \mathrm{ng} / \mathrm{ml}$ ) for $48 \mathrm{~h}$; then JC-1, an indicator of $\Delta \Psi_{\mathrm{m}}$, was added to the cultures. Representative images show amount of fluorescence of monomer or aggregates of JC-1 and nuclei, respectively. $C$ : quantification of caspase- 3 and -9 activity and ratios of JC-1 green to red aggregates from $A$ and $B$. Values are means $\pm \mathrm{SD}(n=$ 3). $* * P<0.01$.
A

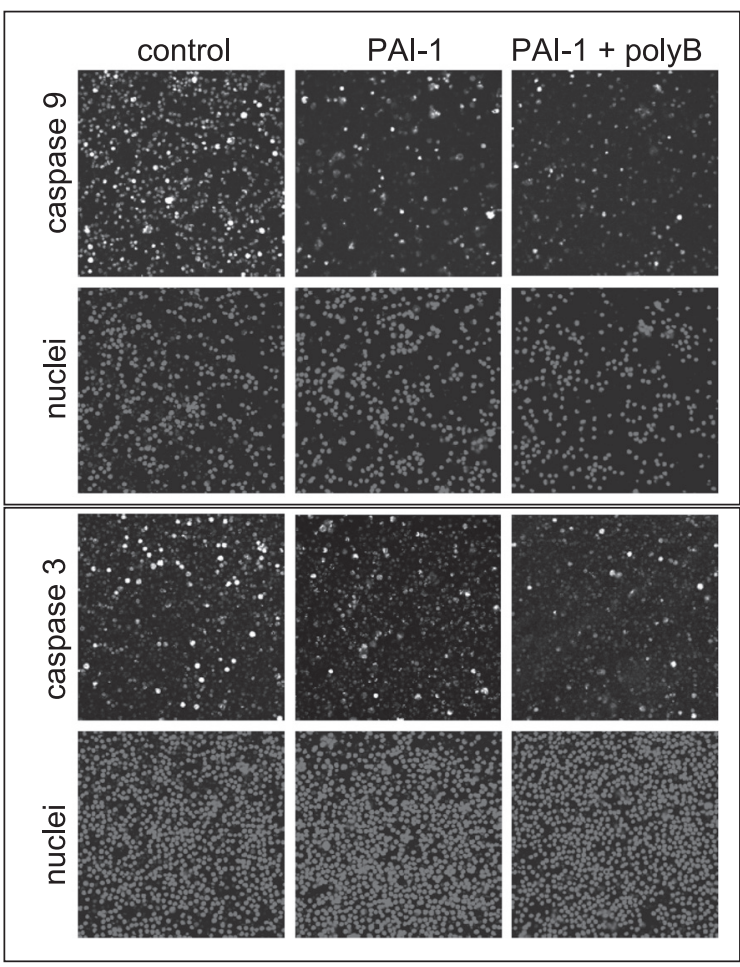

B

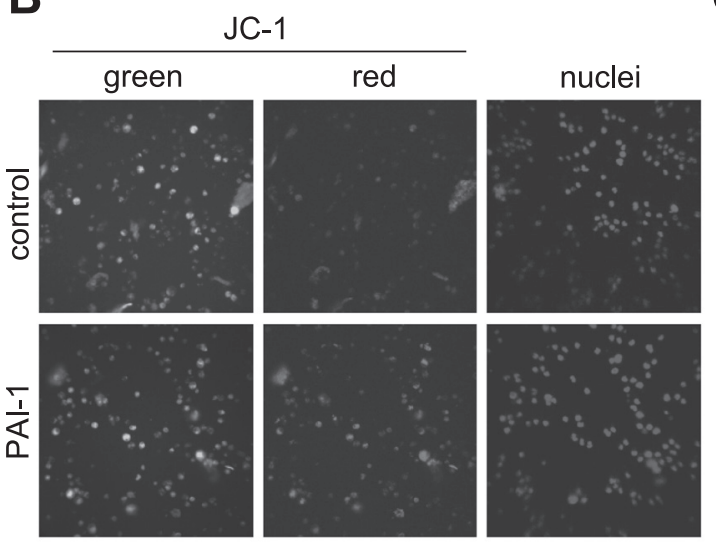

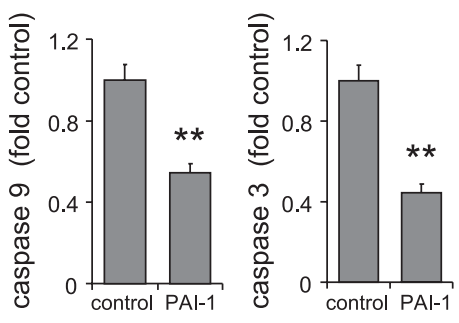

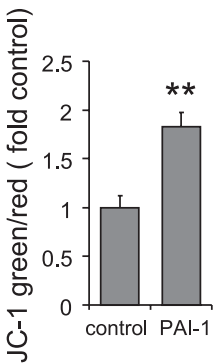

vitronectin can sequester PAI-1 and, therefore, prevent the antiapoptotic effects of PAI-1, binding to vitronectin on the cell surface is not required for the antiapoptotic effects of PAI-1.

We next determined if the antiapoptotic effects of PAI-1 were mediated by interaction with uPAR. As shown in Fig. $6 C$, PAI-1 diminished spontaneous apoptosis in uPAR-deficient $\left(\right.$ upar $^{-/-}$) neutrophils, indicating that uPAR was not required for the inhibitory effects of PAI-1 on apoptosis.

Consistent with previous studies $(12,38)$, addition of antiCD11b antibody to neutrophils resulted in enhanced apoptosis (Fig. 6D). However, PAI-1 was still able to inhibit neutrophil apoptosis, even after incubation of the cells with antibodies to
CD11b (Fig. 6D). These results indicate that the antiapoptotic effects of PAI-1 are independent of the Mac-1 signaling pathway.

While the above-described experiments showed that PAI-1mediated inhibition of neutrophil apoptosis is independent of interactions with uPAR, LRP, Mac-1, and vitronectin, inhibition of $\mathrm{G}$ protein-coupled receptors (GPCRs) with pertussis toxin diminished the inhibitory effect of PAI-1 on apoptosis (Fig. 6E). The concentrations of pertussis toxin used in these experiments did not adversely affect the viability of neutrophils in the absence of PAI-1. These results demonstrate that specific signaling pathways involving the GPCR are required for the antiapoptotic effects of PAI-1. 


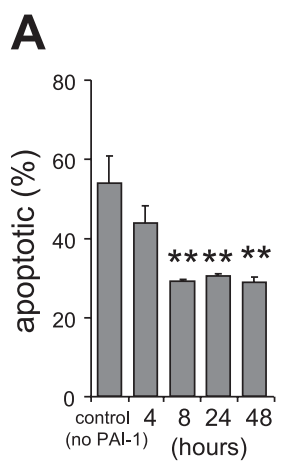

Time of PAI-1 removal from culture (hours)
B

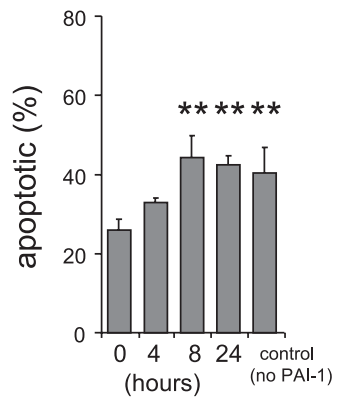

Time of PAl-1 addition after culture initiation (hours)
C

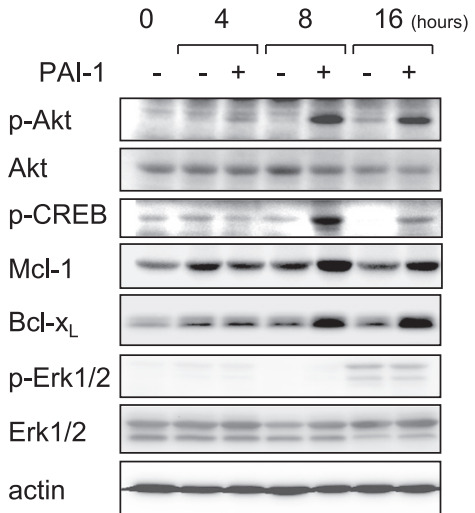

Fig. 4. Time-dependent effects of PAI-1 exposure on neutrophil viability and antiapoptotic signaling. A: PAI-1 (500 ng/ml) was added to neutrophil cultures for 4,8 , or $24 \mathrm{~h}$; then cells were washed, fresh medium without PAI- 1 was added, and culture continued for a total of $48 \mathrm{~h}$. In controls, neutrophils were continuously cultured with or without PAI-1 for $48 \mathrm{~h}$. Percentages of apoptotic and viable cells were determined using annexin/PI staining and flow cytometry. $* * P<0.01$ vs. untreated cells. $B$ : neutrophils were cultured for $0-24 \mathrm{~h}$; then PAI-1 was added to cell cultures. Percentage of apoptotic cells was determined by flow cytometry after a total of $48 \mathrm{~h}$ of culture. $* * P<0.01$ vs. untreated cells. $C$ : representative Western blots showing levels of total and phosphorylated (p) Akt, cAMP response element-binding (CREB) protein, and Erk1/2, as well as amounts of Bcl- $\mathrm{x}_{\mathrm{L}}$ and Mcl-1, after culture of neutrophils with PAI-1 for 0, 4 , or $8 \mathrm{~h}$. A second independent experiment provided similar results.

Exposure of neutrophils to TNF-related apoptosis-inducing ligand (TRAIL) resulted in enhanced apoptosis (Fig. 6F), consistent with previous studies showing the importance of extrinsic induced apoptotic pathways in neutrophil death (27, $31,41)$. Inclusion of PAI-1 in the neutrophil cultures diminished the proapoptotic effects of TRAIL (Fig. 6F). These results demonstrate that PAI-1 diminishes spontaneous and extrinsically mediated neutrophil apoptosis.

PAI-1 deficiency is associated with increased neutrophil apoptosis under in vivo conditions during acute inflammatory lung injury. Although our results with cultured neutrophils demonstrate that PAI-1 has potent antiapoptotic properties, the in vivo relevance of this finding was unclear. To examine this question, LPS-induced ALI was generated in control WT $\left(\mathrm{PAI}-1^{+/+}\right)$and PAI-1 deficient (PAI- $1^{-/-}$) mice. As shown in Fig. 7, $A$ and $B$, apoptosis was significantly increased (i.e., as

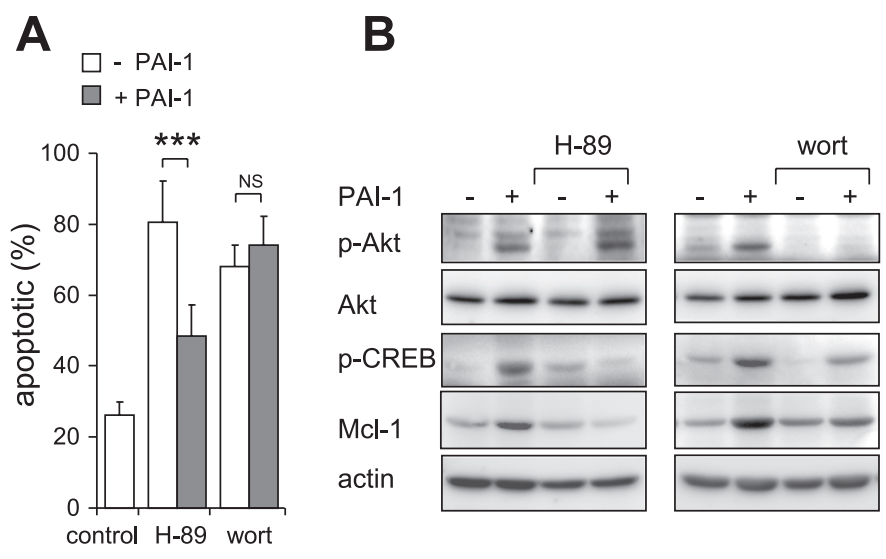

Fig. 5. Antiapoptotic effect of PAI-1 requires Akt activation. A: neutrophil apoptosis after incubation with $\mathrm{H}-89(0$ or $10 \mu \mathrm{M})$ or wortmannin (wort, 0 or $200 \mathrm{nM})$ with or without PAI-1. Values are means $\pm \mathrm{SD}(n=3)$. *** $P<$ $0.001, \mathrm{H}-89$ alone vs. H-89 + PAI-1. $B$ : neutrophils were incubated with H-89 (0 or $10 \mu \mathrm{M})$ or wortmannin $(0$ or $200 \mathrm{nM})$ for $1 \mathrm{~h}$, PAI-1 (0 or $500 \mathrm{ng} / \mathrm{ml})$ was added to the cultures, and culture continued for $8 \mathrm{~h}$. Representative Western blots show effects of H-89 or wortmannin on PAI-1-induced phosphorylation of Akt and CREB and on levels of Mcl-1 and actin. Two additional independent experiments provided similar results. defined by the cells being annexin V-positive) in neutrophils isolated from the lungs of LPS-exposed PAI- $1^{-1-}$ compared with PAI- $1^{+/+}$mice. Consistent with these results, caspase-9 activation was significantly increased among neutrophils isolated from the lungs of PAI- $1^{-/-}$compared with PAI- $1^{+/+}$ mice (Fig. 7C). The number of neutrophils in bronchoalveolar lavage fluid from PAI-1 ${ }^{-1-}$ mice was also decreased compared with bronchoalveolar lavage fluid from PAI-1 ${ }^{+/+}$ mice (Fig. 7D), consistent with enhanced apoptotic death and clearance of pulmonary neutrophils during LPS-induced ALI in PAI $-1^{-1-}$ mice.

\section{DISCUSSION}

Recent studies have reported that PAI-1 can induce pro- and antiapoptotic responses in nonmyeloid cell populations, including fibroblasts and endothelial cells $(3,5,29)$. We have extended those observations and shown that exposure of neutrophils to PAI-1 diminished their progression to apoptotic cell death. Incubation of neutrophils with PAI-1 was accompanied by activation of pathways involving antiapoptotic mediators, including Akt, Mcl-1 and Bcl- $\mathrm{x}_{\mathrm{L}}$, inhibition of caspases-3 and -9 , and preservation of $\Delta \psi_{\mathrm{m}}$. Although previous studies have reported that PAI-1 can bind to and inhibit caspase-3 (11), this does not appear to be the mechanism for the antiapoptotic effects of PAI-1, since caspase-9, which is upstream to caspase-3, was also inhibited in PAI-1-treated neutrophils. Whereas signaling events that involve activation of PKA and CREB, as well as CREB-dependent enhanced expression of Mcl-1, can increase neutrophil viability (24), we did not find a contributory role for these events in the PAI-1-induced reduction of neutrophil apoptosis. Rather, the present experiments identified PI3-K activation as a central event in PAI-1-associated preservation of neutrophil viability. These results are consistent with recent findings of decreased viability of neutrophils isolated from PI3-K $\gamma$-deficient mice and increased viability of neutrophils from phosphatase and tensin homolog (PTEN)-deficient mice (45).

Although interactions between PAI-1 and uPAR/uPA, LRP, and vitronectin are well described, none of these appear to be 


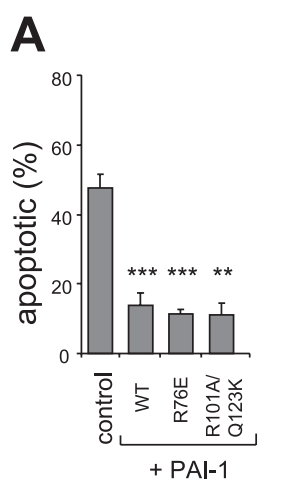

B

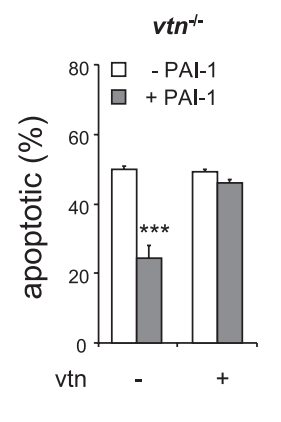

C

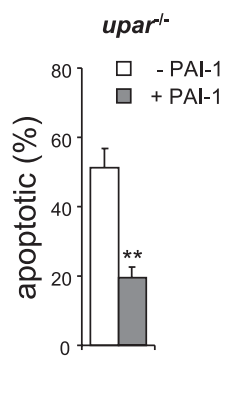

D

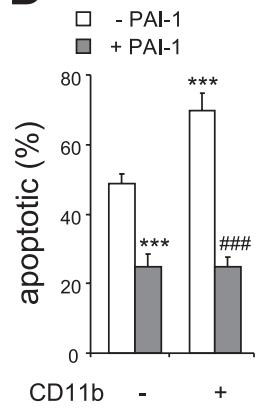

E

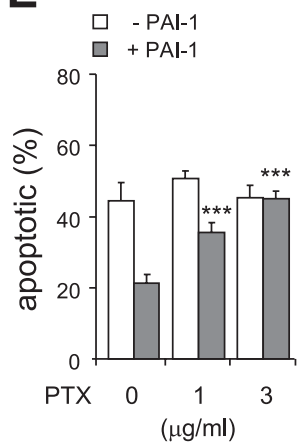

central role in the resolution of inflammation. Our results, showing that PAI-1 has potent antiapoptotic effects in neutrophils, demonstrate a novel proinflammatory property for PAI-1. This antiapoptotic effect of PAI-1 is likely to be

A

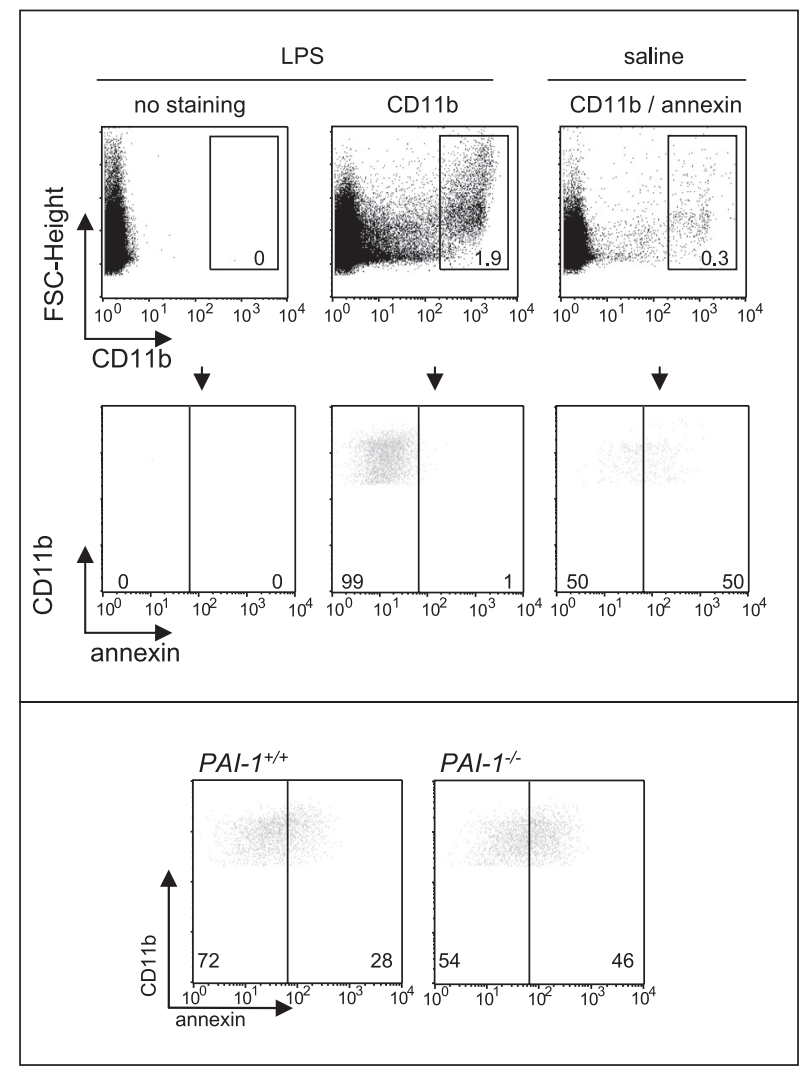

Fig. 6. Effects of PAI-1 and PAI-1 mutants on spontaneous apoptosis among wild-type (WT) and vitronectin- or urokinase-plasminogen activator receptor (uPAR)-deficient $\left(\right.$ upar $^{--}$) neutrophils. A: apoptosis was determined in neutrophils incubated for $48 \mathrm{~h}$ with or without PAI-1 (WT) or PAI-1 mutants $\mathrm{R} 76 \mathrm{E}$ or $\mathrm{R} 101 \mathrm{~A} / \mathrm{Q} 123 \mathrm{~K}$. Values are means $\pm \mathrm{SD}(n=3)$. $* * * P<$ $0.001, * * P<0.01$ vs. untreated. $B$ : PAI-1 (500 ng) was incubated with recombinant vitronectin $(10 \mu \mathrm{g})$ for $60 \mathrm{~min}$ at room temperature and then included for $48 \mathrm{~h}$ in cultures of neutrophils from vitronectin-deficient $\left(v t n^{-1-}\right)$ mice. Cells were also left untreated or cultured with PAI-1 or vitronectin alone. $C$ : apoptosis in neutrophils isolated from par $^{-1-}$ mice incubated with PAI-1 $(0$ or $500 \mathrm{ng} / \mathrm{ml})$ for $48 \mathrm{~h} . * * P<0.01 \mathrm{vs}$. untreated. $D$ : neutrophils were preincubated with or without anti-CD11b antibodies $(0$ or $1 \mu \mathrm{g} / \mathrm{ml})$ for $30 \mathrm{~min}$, cultured with PAI-1 (0 or $500 \mathrm{ng} / \mathrm{ml})$ for $24 \mathrm{~h}$, and then washed and cultured for an additional $24 \mathrm{~h}$. Values are means $\pm \mathrm{SD}$ $(n=3)$. $* * * P<0.001$ vs. untreated. \#\#\#P<0.001 vs. anti-CD11b alone. $E$ : diminished antiapoptotic effects of PAI-1 in neutrophils treated with pertussis toxin (PTX). Neutrophils were cultured with PAI-1 (0 or 500 $\mathrm{ng} / \mathrm{ml})$, PTX $(0,1$, or $3 \mu \mathrm{g} / \mathrm{ml})$, or PAI- $1+$ PTX for $48 \mathrm{~h}$. Values are means \pm $\mathrm{SD}(n=3)$. $* * * P<0.001$, vs. PAI-1 alone. $F$ : apoptosis in neutrophils after exposure to PAI-1 ( 0 or $500 \mathrm{ng} / \mathrm{ml})$ for $4 \mathrm{~h}$ followed by inclusion of TNF-related apoptosis-inducing ligand (TRAIL, $30 \mathrm{ng} / \mathrm{ml}$ ) in the cultures for an additional $44 \mathrm{~h}$. Values are means $\pm \operatorname{SD}(n=3)$. $* * * P<0.001$ vs. untreated. $\# \# \#>0.01$ vs. TRAIL alone.

responsible for the antiapoptotic effects of PAI-1 among neutrophils. In particular, PAI-1 maintained its antiapoptotic effects and significantly increased the viability of neutrophils isolated from uPAR- or vitronectin-deficient mice. PAI-1 mutants unable to interact with vitronectin or LRP still were able to decrease neutrophil apoptosis. In contrast, treatment of neutrophils with pertussis toxin, which inhibits GPCR signaling, eliminated the antiapoptotic effects of PAI-1. The involvement of interactions between PAI-1-, PI3-K-, and GPCRrelated signaling in modulating neutrophil viability is consistent with a recent study (42) showing that GPCR-mediated regulation of Akt activation plays an important role in regulating spontaneous death in neutrophils.

Clearance of activated neutrophils through activation of cellular programs involving constitutive cell death plays a

B

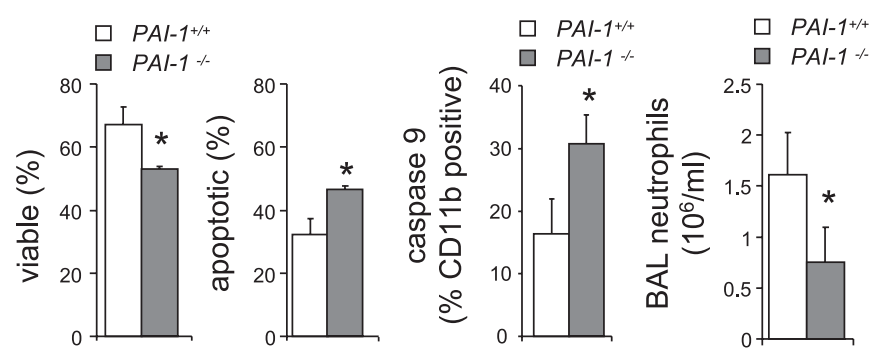

Fig. 7. PAI-1 deficiency is associated with diminished viability and increased apoptosis of pulmonary neutrophils in mice with LPS-induced acute lung injury. A, top: representative plots with indicated percentages of neutrophils (i.e., CD11b-positive cells) and CD11b- and annexin V-positive/negative cells from lungs of mice treated intratracheally with saline (control) or LPS (1 $\mathrm{mg} / \mathrm{kg}$ ) $24 \mathrm{~h}$ previously. Similar results were obtained from 2 additional independent experiments. A, bottom: representative plots showing percentage of CD11b-positive cells from control (PAI- $1^{+/+}$) or PAI- $1^{-/-}$mice treated intratracheally with saline (control) or LPS $(1 \mathrm{mg} / \mathrm{kg}) 24 \mathrm{~h}$ previously. $B$ : percentage of apoptotic or nonapoptotic neutrophils (annexin V-positive or -negative cells) obtained from PAI-1 ${ }^{+/+}$or PAI- $1^{-/-}$(viable) mice treated intratracheally with saline (control) or LPS $(1 \mathrm{mg} / \mathrm{kg}) 24 \mathrm{~h}$ previously. Values are means $\pm \mathrm{SD}(n=$ $3) . * P<0.05$ vs. PAI- $1^{-1-}$. $C$ : increase in caspase-9 activity among CD11bpositive cells from lungs of PAI- $1^{+/+}$and PAI- $1^{-/-}$mice given LPS intratracheally $24 \mathrm{~h}$ previously. Values are means $\pm \mathrm{SD}(n=3) . * P<0.05$ vs. PAI- $1^{-1-}$. $D$ : significant decrease in number of neutrophils in bronchoalveolar lavage (BAL) fluid of PAI- $1^{-1-}$ compared with PAI- $1^{+/+}$mice. Values are means $\pm \mathrm{SD}(n=3) . * P<0.05$ vs. PAI- $1^{-1-}$. 
particularly important in clinical settings, such as ALI and sepsis, in which PAI-1 levels are increased and neutrophil accumulation in the lungs and other anatomic sites contributes to organ dysfunction and death. In particular, by prolonging the viability of neutrophils activated to produce proinflammatory mediators, PAI-1 may contribute to exacerbation of inflammatory processes in which neutrophils play a role.

The enhanced production of PAI-1 during infectious and noninfectious inflammatory conditions can have beneficial and deleterious consequences for the host. In particular, upregulation and secretion of PAI-1 in endothelial and epithelial cells, by enhancing neutrophil chemotaxis (23), can facilitate trafficking of neutrophils into infectious foci and subsequent clearance of bacteria. In contrast, extended exposure of neutrophils to PAI-1 may inhibit resolution of inflammation through prolongation of the presence in the lungs and other organs of neutrophils activated to produce tissue-damaging proinflammatory mediators such as reactive oxygen species and cytokines. Additionally, PAI-1 also functions as a potent "don't eat me" signal, reducing uptake of neutrophils by macrophages. The inhibitory effect of PAI-1 on efferocytosis, coupled with the ability of PAI-1 to diminish constitutive cell death in neutrophils, is likely to potentiate the magnitude and duration of neutrophil-driven inflammatory responses. Indeed, previous studies have shown more severe pulmonary injury after LPS exposure or hyperoxia in PAI- $1^{+/+}$than PAI-1 ${ }^{-1-}$ mice (7), a finding consistent with our results demonstrating increased numbers of apoptotic neutrophils in the lungs of PAI-1-deficient mice after pulmonary exposure to LPS. Previous studies have shown increased severity of bleomycin-induced lung injury and fibrosis in transgenic mice overexpressing PAI-1 (14). As the early stages of lung injury due to bleomycin are characterized by neutrophil infiltration (18), it is possible that reduced neutrophil apoptosis and clearance contribute to the enhanced susceptibility of PAI-1-overexpressing mice to bleomycin-associated lung injury. Thus pharmacological inhibition of PAI-1 may be beneficial in accelerating the resolution of inflammatory responses characterized by a prominent neutrophilic component.

\section{ACKNOWLEDGMENTS}

We thank Celeste P. Bell and Enid Keyser for technical support and the Flow Cytometry Core, Arthritis and Musculoskeletal Center at the University of Alabama at Birmingham.

\section{GRANTS}

This work was supported in part by National Institutes of Health Grants HL-76206 and GM-87748 to E. Abraham. The Flow Cytometry Core, Arthritis and Musculoskeletal Center at the University of Alabama at Birmingham is supported by National Institute of Arthritis and Musculoskeletal and Skin Diseases Grant P30 AR-48311.

\section{DISCLOSURES}

No conflicts of interest, financial or otherwise, are declared by the authors.

\section{REFERENCES}

1. Abraham E. Neutrophils and acute lung injury. Crit Care Med 31: S195-S199, 2003.

2. Akgul C, Moulding DA, Edwards SW. Molecular control of neutrophil apoptosis. FEBS Lett 487: 318-322, 2001.

3. Al-Fakhri N, Chavakis T, Schmidt-Woll T, Huang B, Cherian SM, Bobryshev YV, Lord RS, Katz N, Preissner KT. Induction of apoptosis in vascular cells by plasminogen activator inhibitor-1 and high molecular weight kininogen correlates with their anti-adhesive properties. Biol Chem 384: 423-435, 2003.

4. Alfano D, Franco P, Vocca I, Gambi N, Pisa V, Mancini A, Caputi M, Carriero MV, Iaccarino I, Stoppelli MP. The urokinase plasminogen activator and its receptor: role in cell growth and apoptosis. Thromb Haemost 93: 205-211, 2005.

5. Balsara RD, Castellino FJ, Ploplis VA. A novel function of plasminogen activator inhibitor-1 in modulation of the AKT pathway in wild-type and plasminogen activator inhibitor-1-deficient endothelial cells. J Biol Chem 281: 22527-22536, 2006.

6. Balsara RD, Ploplis VA. Plasminogen activator inhibitor-1: the doubleedged sword in apoptosis. Thromb Haemost 100: 1029-1036, 2008.

7. Barazzone C, Belin D, Piguet PF, Vassalli JD, Sappino AP. Plasminogen activator inhibitor-1 in acute hyperoxic mouse lung injury. J Clin Invest 98: 2666-2673, 1996.

8. Bodine PV. Wnt signaling control of bone cell apoptosis. Cell Res 18: 248-253, 2008.

9. Brass DM, Hollingsworth JW, McElvania-Tekippe E, Garantziotis S, Hossain I, Schwartz DA. CD14 is an essential mediator of LPS-induced airway disease. Am J Physiol Lung Cell Mol Physiol 293: L77-L83, 2007.

10. Brown KA, Brain SD, Pearson JD, Edgeworth JD, Lewis SM, Treacher DF. Neutrophils in development of multiple organ failure in sepsis. Lancet 368: 157-169, 2006.

11. Chen Y, Kelm RJ ,Jr, Budd RC, Sobel BE, Schneider DJ. Inhibition of apoptosis and caspase- 3 in vascular smooth muscle cells by plasminogen activator inhibitor type-1. J Cell Biochem 92: 178-188, 2004.

12. Coxon A, Tang T, Mayadas TN. Cytokine-activated endothelial cells delay neutrophil apoptosis in vitro and in vivo. A role for granulocyte/ macrophage colony-stimulating factor. J Exp Med 190: 923-934, 1999.

13. Darzynkiewicz Z, Juan G, Li X, Gorczyca W, Murakami T, Traganos F. Cytometry in cell necrobiology: analysis of apoptosis and accidental cell death (necrosis). Cytometry 27: 1-20, 1997.

14. Eitzman DT, McCoy RD, Zheng X, Fay WP, Shen T, Ginsburg D, Simon RH. Bleomycin-induced pulmonary fibrosis in transgenic mice that either lack or overexpress the murine plasminogen activator inhibitor-1 gene. J Clin Invest 97: 232-237, 1996.

15. Foster WM, Walters DM, Longphre M, Macri K, Miller LM. Methodology for the measurement of mucociliary function in the mouse by scintigraphy. J Appl Physiol 90: 1111-1117, 2001.

16. Fox S, Leitch AE, Duffin R, Haslett C, Rossi AG. Neutrophil apoptosis: relevance to the innate immune response and inflammatory disease. $J$ Innate Immun 2: 216-227, 2010.

17. Garlichs CD, Eskafi S, Cicha I, Schmeisser A, Walzog B, Raaz D, Stumpf C, Yilmaz A, Bremer J, Ludwig J, Daniel WG. Delay of neutrophil apoptosis in acute coronary syndromes. J Leukoc Biol 75: $828-835,2004$.

18. Gasse P, Mary C, Guenon I, Noulin N, Charron S, SchnyderCandrian S, Schnyder B, Akira S, Quesniaux VF, Lagente V, Ryffel B, Couillin I. IL-1R1/MyD88 signaling and the inflammasome are essential in pulmonary inflammation and fibrosis in mice. J Clin Invest 117: 3786-3799, 2007.

19. Gilroy DW, Lawrence T, Perretti M, Rossi AG. Inflammatory resolution: new opportunities for drug discovery. Nat Rev Drug Discov 3: 401-416, 2004.

20. Keel M, Ungethum U, Steckholzer U, Niederer E, Hartung T, Trentz O, Ertel W. Interleukin-10 counterregulates proinflammatory cytokineinduced inhibition of neutrophil apoptosis during severe sepsis. Blood 90: 3356-3363, 1997.

21. Lademann UA, Romer MU. Regulation of programmed cell death by plasminogen activator inhibitor type 1 (PAI-1). Thromb Haemost 100: 1041-1046, 2008.

22. Lopez-Alemany R, Redondo JM, Nagamine $\mathbf{Y}$, Munoz-Canoves $\mathbf{P}$. Plasminogen activator inhibitor type-1 inhibits insulin signaling by competing with $\alpha_{\mathrm{v}} \beta_{3}$-integrin for vitronectin binding. Eur J Biochem 270: 814-821, 2003.

23. Marshall LJ, Ramdin LS, Brooks T, DPhil PC, Shute JK. Plasminogen activator inhibitor-1 supports IL-8-mediated neutrophil transendothelial migration by inhibition of the constitutive shedding of endothelial IL-8/ heparan sulfate/syndecan-1 complexes. J Immunol 171: 2057-2065, 2003.

24. Martin MC, Dransfield I, Haslett C, Rossi AG. Cyclic AMP regulation of neutrophil apoptosis occurs via a novel protein kinase A-independent signaling pathway. J Biol Chem 276: 45041-45050, 2001.

25. Myohanen H, Vaheri A. Regulation and interactions in the activation of cell-associated plasminogen. Cell Mol Life Sci 61: 2840-2858, 2004. 
26. Park YJ, Liu G, Lorne EF, Zhao X, Wang J, Tsuruta Y, Zmijewski J, Abraham E. PAI-1 inhibits neutrophil efferocytosis. Proc Natl Acad Sci USA 105: 11784-11789, 2008.

27. Paunel-Gorgulu A, Zornig M, Logters T, Altrichter J, Rabenhorst U, Cinatl J, Windolf J, Scholz M. Mcl-1-mediated impairment of the intrinsic apoptosis pathway in circulating neutrophils from critically ill patients can be overcome by Fas stimulation. J Immunol 183: 6198-6206, 2009.

28. Prabhakaran P, Ware LB, White KE, Cross MT, Matthay MA, Olman MA. Elevated levels of plasminogen activator inhibitor-1 in pulmonary edema fluid are associated with mortality in acute lung injury. Am J Physiol Lung Cell Mol Physiol 285: L20-L28, 2003.

29. Romer MU, Larsen L, Offenberg H, Brunner N, Lademann UA. Plasminogen activator inhibitor 1 protects fibrosarcoma cells from etoposide-induced apoptosis through activation of the PI3K/Akt cell survival pathway. Neoplasia 10: 1083-1091, 2008.

30. Rossi AG, Sawatzky DA, Walker A, Ward C, Sheldrake TA, Riley NA, Caldicott A, Martinez-Losa M, Walker TR, Duffin R, Gray M, Crescenzi E, Martin MC, Brady HJ, Savill JS, Dransfield I, Haslett C. Cyclin-dependent kinase inhibitors enhance the resolution of inflammation by promoting inflammatory cell apoptosis. Nat Med 12: 1056-1064, 2006.

31. Rowe SJ, Allen L, Ridger VC, Hellewell PG, Whyte MK. Caspase-1deficient mice have delayed neutrophil apoptosis and a prolonged inflammatory response to lipopolysaccharide-induced acute lung injury. J Immunol 169: 6401-6407, 2002.

32. Savill J, Dransfield I, Gregory C, Haslett C. A blast from the past: clearance of apoptotic cells regulates immune responses. Nat Rev Immunol 2: 965-975, 2002.

33. Schar CR, Jensen JK, Christensen A, Blouse GE, Andreasen PA, Peterson CB. Characterization of a site on PAI-1 that binds to vitronectin outside of the somatomedin B domain. J Biol Chem 283: 28487-28496, 2008.

34. Smiley ST, Reers M, Mottola-Hartshorn C, Lin M, Chen A, Smith TW, Steele GD Jr, Chen LB. Intracellular heterogeneity in mitochondrial membrane potentials revealed by a J-aggregate-forming lipophilic cation JC-1. Proc Natl Acad Sci USA 88: 3671-3675, 1991.

35. Smith HW, Marshall CJ. Regulation of cell signalling by uPAR. Nat Rev Mol Cell Biol 11: 23-36, 2010.

36. Stefansson S, Lawrence DA. The serpin PAI-1 inhibits cell migration by blocking integrin- $\alpha_{\mathrm{v}} \beta_{3}$ binding to vitronectin. Nature 383: 441-443, 1996.

37. Stefansson S, Muhammad S, Cheng XF, Battey FD, Strickland DK, Lawrence DA. Plasminogen activator inhibitor-1 contains a cryptic high affinity binding site for the low density lipoprotein receptor-related protein. J Biol Chem 273: 6358-6366, 1998.

38. Walzog B, Jeblonski F, Zakrzewicz A, Gaehtgens P. $\beta_{2}$-Integrins (CD11/CD18) promote apoptosis of human neutrophils. FASEB $J 11$ : 1177-1186, 1997.
39. Wardle DJ, Burgon J, Sabroe I, Bingle CD, Whyte MK, Renshaw SA. Effective caspase inhibition blocks neutrophil apoptosis and reveals Mcl-1 as both a regulator and a target of neutrophil caspase activation. PLoS One 6: e15768, 2011.

40. Ware LB, Matthay MA, Parsons PE, Thompson BT, Januzzi JL, Eisner MD. Pathogenetic and prognostic significance of altered coagulation and fibrinolysis in acute lung injury/acute respiratory distress syndrome. Crit Care Med 35: 1821-1828, 2007.

41. Witko-Sarsat V, Mocek J, Bouayad D, Tamassia N, Ribeil JA, Candalh C, Davezac N, Reuter N, Mouthon L, Hermine O, PederzoliRibeil M, Cassatella MA. Proliferating cell nuclear antigen acts as a cytoplasmic platform controlling human neutrophil survival. J Exp Med 207: 2631-2645, 2010.

42. Xu Y, Loison F, Luo HR. Neutrophil spontaneous death is mediated by down-regulation of autocrine signaling through GPCR, PI3K $\gamma$, ROS, and actin. Proc Natl Acad Sci USA 107: 2950-2955, 2010.

43. Xu Z, Balsara RD, Gorlatova NV, Lawrence DA, Castellino FJ, Ploplis VA. Conservation of critical functional domains in murine plasminogen activator inhibitor-1. J Biol Chem 279: 17914-17920, 2004.

44. Zhao X, Zmijewski JW, Lorne E, Liu G, Park YJ, Tsuruta Y, Abraham E. Activation of AMPK attenuates neutrophil proinflammatory activity and decreases the severity of acute lung injury. Am J Physiol Lung Cell Mol Physiol 295: L497-L504, 2008.

45. Zhu D, Hattori H, Jo H, Jia Y, Subramanian KK, Loison F, You J, Le Y, Honczarenko M, Silberstein L, Luo HR. Deactivation of phosphatidylinositol 3,4,5-trisphosphate/Akt signaling mediates neutrophil spontaneous death. Proc Natl Acad Sci USA 103: 14836-14841, 2006.

46. Zmijewski JW, Lorne E, Banerjee S, Abraham E. Participation of mitochondrial respiratory complex III in neutrophil activation and lung injury. Am J Physiol Lung Cell Mol Physiol 296: L624-L634, 2009.

47. Zmijewski JW, Lorne E, Zhao X, Tsuruta Y, Sha Y, Liu G, Abraham E. Anti-inflammatory effects of hydrogen peroxide in neutrophil activation and acute lung injury. Am J Respir Crit Care Med 179: 694-704, 2009.

48. Zmijewski JW, Lorne E, Zhao X, Tsuruta Y, Sha Y, Liu G, Siegal GP, Abraham E. Mitochondrial respiratory complex I regulates neutrophil activation and severity of lung injury. Am J Respir Crit Care Med 178: 168-179, 2008.

49. Zmijewski JW, Moellering DR, Le Goffe C, Landar A, Ramachandran A, Darley-Usmar VM. Oxidized LDL induces mitochondrially associated reactive oxygen/nitrogen species formation in endothelial cells. Am J Physiol Heart Circ Physiol 289: H852-H861, 2005.

50. Zmijewski JW, Zhao X, Xu Z, Abraham E. Exposure to hydrogen peroxide diminishes NF- $\kappa \mathrm{B}$ activation, IкB- $\alpha$ degradation, and proteasome activity in neutrophils. Am J Physiol Cell Physiol 293: C255-C266, 2007. 